\title{
The Role of Cell Therapy in the Treatment of Epilepsy: Lessons from Animal Models and Clinical Trials
}

\author{
Magda Giordano \\ Instituto de Neurobiología, Universidad Nacional Autónoma de México, \\ Mexico
}

\section{Introduction}

The notion of replacing brain cells affected by a particular disease or unable to synthesize a molecule crucial for adequate brain function has been around for many years. The first experiments entailed the transplantation of adult tissue into an adult or young animal; they were met with limited success (Björklund \& Stenevi, 1984). Later, scientists started working with fetal tissue, because this tissue fares better when dissected, axons are shorter, cells are still dividing, and growth factors are present in the tissue. These studies were more successful and led to clinical trials using human fetal tissue, and autologous transplants of adrenal chromaffin cells, especially for Parkinson's disease (Freed, 1991). Transplants were first used in this neurodegenerative disorder because it was assumed that the main problem was the lack of dopamine in the striatum, and this neurotransmitter could be readily provided by chromaffin cells from the adrenal medulla or by mesencephalic dopaminergic cells. Initial preclinical studies had shown, using the 6-OHDA model developed by Ungerstedt (Ungerstedt 1968; Ungerstedt \& Arbuthnott, 1970), that intrastriatal grafts of mesencephalic cells could reduce the number of ipsilateral or contralateral rotations induced by apomorphine or amphetamine, suggesting that the dopaminergic tone had been restored in the lesioned striatum. These studies led to others using fimbria fornix lesions (e.g., Dunnett et al., 1982), diabetes insipidus model (e.g., Gash \& Sladek, 1980), Huntington's disease models (e.g., Norman et al., 1989), and epilepsy models (e.g., Castillo et al., 2006). In addition to the experiments showing functional effects of the transplants, there were others looking for the mechanisms underlying the effects of the transplans. A series of studies showed that transplanted cells could establish reciprocal anatomical connections with the host (Wictorin, 1992; Murata et al., 1990). A couple of studies using electrophysiology, and markers or cell activation showed that these connections were functional (Xu et al., 1991; Rutherford et al., 1987; Labandeira-Garcia \& Guerra, 1994). Neuroscientists involved in this field concluded that neural transplants could affect the host brain by releasing growth factors, and neurotransmitters, and by establishing functional connections with the host brain, thus reestablishing lost circuits.

However, the source of tissue for transplantation was still an issue to be considered. Fetal tissue was not readily available in all countries, and its use implicated ethical and legal 
issues not easily resolved. In addition, fetal tissue included all kinds of cells, and in spite of the immuno-privileged status of the brain, it could lead to an inflammatory response in the host. Autologous transplants of chromaffin cells (Freed et al., 1990) and xeno-transplants (Fink et al. 2000) had been used as an alternative source of tissue for transplantation. Then, with the advent of new molecular biology techniques, cell lines with particular properties and characteristics were developed. GABAergic cell lines proved easier to develop than dopaminergic cell lines, and given the fact that epilepsy has been considered as a disorder in which there is an imbalance between excitation and inhibition, these cell lines started to be tested in epilepsy animal models. More recently, once it was demonstrated that Cajal's notion that in the adult nervous system neurons no longer divide was incorrect, and that there are neurogenic pools in the adult brain (Nottebohm, 2002), the potential use of these immature cells for transplantation became a possibility. Furthermore, a myriad of studies started looking for factors to differentiate these immature nerve cells into the desired type of nerve cell, dopaminergic, cholinergic, GABAergic, among others (Vazin \& Freed, 2010; Mejía-Toiber et al., in press). Cell lines could be developed from these adult but immature cells, thus solving the problem of having a source of tissue for transplantation. Moreover, now we know that cells, such as fibroblasts can be reprogrammed into neuronal cells (e.g., Takahashi \& Yamanaka, 2006), thus, in theory the host could eventually replace its own damaged cells. In this brief overview of the field of neural transplantation, we have seen how the sources of tissue for transplantation have expanded, the techniques have been refined, and new possibilities have emerged to try and restore function in the nervous system. Still, questions remain, how is it that the new cells can modify the function of the host nervous system, is it the transplant that changes the host brain and takes some of its functions, or is it the host brain itself that is modified as a result of the presence of the alien cells in its midst. Is it necessary to transplant new cells into the brain, or do we have to learn how to activate the neurogenesis that is already taking place in the adult brain. How can cells be differentiated without posing a risk for the host, which plasmids are safe to us, and which are not. In the following sections we will focus on the advances of neural transplants in animal models of epilepsy, and in the clinical setting in Parkinson's disease.

\section{Preclinical studies using cell transplants of fetal tissue and neural stem cells in animal models of epilepsy}

Epilepsy is a neurological disorder with a prevalence of about 1\% (Morimoto, Fahnestock et al. 2004) characterized by seizures that occur in a spontaneous and recurrent manner. Seizures are classified as generalized and can manifest themselves as uncontrolled muscular activity or as a sudden interruption of physical and mental activity (absence seizures); or as focal seizures, that are classified according to their manifestation, i.e., if they involve psychic or sensory phenomena, motor or autonomic components, loss of awareness, or evolving to a bilateral, convulsive seizure (Berg et al., 2010). Epileptic seizures are the result of abnormal, excessive and synchronic discharges of groups of neurons that occur as a result of changes in synaptic function and intrinsic properties of neurons that upset the balance between inhibitory and excitatory neurotransmission, favoring the latter (Cossart et al., 2001). In the recent document published by the International League Against Epilepsy (ILAE) Commission on Classification and 
Terminology (Berg et al., 2010), the underlying type of causes of epilepsy are considered to be genetic, structural-metabolic or unknown.

Epilepsy is one of the neurological disorders that could benefit from transplantation of cells, since some types of epilepsy are focal, and in the case of generalized seizures they can be suppressed by local injections of GABAergic agents into particular areas of the brain such as the substantia nigra, or piriform cortex (Gale, 1992). Indeed, Kokaia et al. (1994) observed a reduction in generalized seizures in rats previously kindled in the amygdala when GABAreleasing polymer matrices were implanted bilaterally and dorsal to the substantia nigra. The effect lasted until GABA release from the polymer matrices was reduced. Thus, local delivery of an inhibitory neurotransmitter could reduce the neuronal excitability in brain regions from which seizures originate or in brain regions from which they propagate to the rest of the brain.

Initially, studies using transplants in epilepsy models used fetal tissue with some success. Barry et al., (1987) (Table 1), evaluated the effect of fetal noradrenergic transplants in the hippocampus using the kindling model of epilepsy. This model consists in the use of repeated subthreshold electrical stimulations of specific regions of the Central Nervous System (CNS). Afterwards, the animal presents focal epileptiform seizures that then generalize to the rest of the brain. The work of Barry et al. (1989) involved first, the administration of 6-hydroxydopamine (6-OHDA) icv, and then the transplant of fetal noradrenergic cells into the hippocampus. The authors of the study found that animals required a greater number of stimulations to induce the various phases of kindling, in comparison with rats that did not receive the transplants. Also the delay in kindling was related to the density of innervation of the transplant in the host hippocampus. They obtained similar results when transplanting cells of the locus coeruleus into the amygdala and piriform cortex (1989) (see Table 1). A study using noradrenergic cells obtained from locus coeruleus (LC) from E13-E14 rats showed that these cells could reinstate noradrenergic transmission in the noradrenaline-depleted hippocampus (Bengzon et al., 1991). In this particular study, they measured noradrenaline-release using microdialysis after electrical stimulation of the hippocampus, and observed that noradrenaline release from intrinsic and grafted LC neurons occurred concurrently with their seizure suppressing action; thus LC grafts in the hippocampus appeared to be functionally integrated into the host brain, at least during generalized kindled seizures (Bengzon et al., 1991).

Fetal GABAergic cells have also been used with varying degrees of success in other epilepsy models. Fine et al. (1990) used the pilocarpine model in rats with ibotenic acid striatal lesions. Fetal GABAergic cells from the ganglionic eminence (E16) were transplanted into the substantia nigra pars reticulata $(\mathrm{SNr})$, and suppressed the motor seizures; however, similar effects were observed after sciatic nerve transplants, suggesting a non-specific effect. Almost a decade later, Löscher et al., (1998) implanted fetal striatal GABAergic neurons into the substantia nigra in fully kindled animals, and evaluated the threshold for focal discharges (ADT), afterdischarge duration and severity, and duration of seizures during ADT. They found a significant increase in ADT and marked reduction in seizure severity compared with pre-transplantation values; however, the seizure-suppressing effect of GABAergic grafts was not permanent but slowly disappeared over the weeks after transplantation (Löscher et al., 1998).

Another decade later, better results were obtained by Rao et al., (2007) and Hattiangady et al., (2008) when these groups evaluated the effects of transplants of hippocampal cells 
(E19), and lateral ganglionic eminence (E15) into the hippocampus in a model of spontaneous recurrent motor seizures (SRMS), respectively. Rao et al., (2007) pretreated the cells with brain derived neurotrophic factor, and neurotrophin-3, plus a caspase inhibitor, or with fibroblast growth factor (FGF-2). They observed that hippocampal cells not treated with trophic factors failed to reduce the SMRS, in contrast to those treated with the trophic factors and the caspase inhibitor; greater survival was observed with FGF-2. Hattiangady et al., (2008) pretreated precursor cells with FGF-2 and a caspase inhibitor, and found an important reduction in SRMS induced by kainic acid. In addition they found that $69 \%$ of surviving transplanted neurons differentiated into GABAergic cells suggesting that the reduction in seizures is related with increased inhibitory control in the hippocampus.

Stem cells with their properties of self-renewal and multipotentiality (Wang et al., 2007) represent another source for transplantation into the nervous system. Pluripotent stem cells (PSC) can generate cells from all three embryonic germ layers, mesoderm, endoderm and ectoderm. Two types of mammalian PSC have been identified, the embryonic stem (ES) cells derived from the inner cell mass of the blastocyst, and embryonic germ (EG) cells obtained from post-implantation embryos (Yu \& Thomson, 2008). Recent studies have identified different means of obtaining desired lineages from these human ES, for example neural stem cells (NSC) (Carpenter et al., 2001; Reubinoff et al., 2001; Zhang et al., 2001), further differentiated into midbrain dopaminergic neurons (e.g. Perrier et al., 2004), neural crest lineages (Lee et al., 2010), and neural progenitor cells from human EG cells (Pan et al., 2005). Various groups have also described differentiation of mouse stem cells into neural precursors, (e.g. Westmoreland et al., 2001; Kim et al., 2002; Barberi et al., 2003; Lang et al., 2004), and found positive functional effects after transplantation (Rodriguez-Gomez et al., 2007).

In terms of their potential use in epilepsy models, it has been shown that NSC derived from the medial ganglionic eminence and transplanted in the hippocampus of adult rats showing spontaneous recurrent motor seizures, reduced motor seizures, but did not restore cognitive impairments (Waldau et al., 2010). The NSC differentiated mostly into astrocytes, neurons, and oligodendrocyte progenitors. About $50 \%$ or the cells expressed GDNF and $10 \%$ expressed GABA. NSC grafts restored GDNF expression in hippocampal astrocytes. The authors of the study suggest that the addition of new GABA neurons plus GDNF positive cells may underlie the therapeutic effects they observed.

A different group has developed adenosine-releasing ES cells, by disruption of both alleles of adenosine kinase (Adk) which phosphorylates adenosine in eukaryotes and catalyzes the reaction: Adenosine $+\mathrm{ATP}=\mathrm{ADP}+\mathrm{AMP}$. The cells were encapsulated in semipermeable polymer membranes and implanted into the lateral ventricles of kindled rats (Güttinger et al., 2005). The authors observed transient protection from convulsive seizures and a profound reduction of afterdischarge activity in EEG recordings. However, they suggest that long-term seizure suppression was precluded by limited viability of the encapsulated cells (Güttinger et al., 2005). In a more recent study with male SpragueDawley rats ( $\mathrm{Li}$ et al, 2007) the same group derived NSC from $A d k-/-$ or $A d k+/+$ ES cells. They implanted them into the hippocampus before kindling, and compared Adk-/- cells to adenosine releasing baby hamster kidney cells $A d k-/-$ (BHK-AK2), and to wild type NSC. They observed that wild type NSC delayed the development of seizures; BHK-AK2 exerted a moderate protection, whereas Adk-/-NSC retarded epileptogenesis during 
kindling development and prevented the occurrence of generalized seizures. The effect was sustained for 3 weeks; 26 days after grafting, histological analysis revealed dense cellular transplants in the vicinity of the injection tract, with $56 \%$ expressing mature neuronal markers (NeuN).

NSC engineered to express enhanced green fluorescent protein under the control of the tau promoter were transplanted one month after pilocarpine treatment in the hippocampus of Wistar male rats (Rüschenschmidt et al., 2005). Electrophysiological recordings 13-34 days after transplantation showed that the NSC developed characteristic intrinsic and synaptic neuronal properties, and received excitatory and inhibitory synaptic inputs; there was no evidence of tumor formation. Jing et al. (2009) described the transplantation into the hippocampus one-week after kainic acid-induced status epilepticus (SE) of NSC obtained from the subventricular zone of green fluorescent protein-expressing Sprague Dawley rats. In this study an infusion of erythropoietin was delivered by means of an osmotic pump into the right lateral ventricle. Erythropoietin $(\mathrm{EPO})$ is a glycoprotein produced primary in the kidney but also produced locally in neural tissues, according to the authors it has shown neuroprotective effects in nervous system disorders including during the process of SE. The results of this study indicated that NSC transplants were able to prevent the development of SRMS through the suppression of aberrant mossy fiber sprouting and by increasing the number of inhibitory neurons. EPO infusion increased survival but not differentiation or migration of NSC; in terms of effects on EEG, no differences were observed between NSC + EPO, and NSC + vehicle groups.

Human NSC have also been used in models of SE. Chu et al (2004) obtained human NSC from the ventricular zone of embryonic brain (15-weeks gestation); one of the clones obtained was infected with a retroviral vector encoding $\beta$-galactosidase $(\beta$-gal) and puromycin-resistant genes. These cells were injected intravenously in a tail vein of male Sprague-Dawley rats, 24-h after pilocarpine-induced SE; the control group received only vehicle. Six weeks later histological analysis or electrophysiological recordings of hippocampal slices took place. In the transplanted group the authors observed a reduction of convulsive seizures; $\beta$-gal+ cells were found in the hippocampal area (CA1, subiculum, hilus of the dentate gyrus, CA3), amygdala, and piriform cortex; in kidney, lungs, and spleen, without evidence of tumor formation. In rats without SE, no cells were found in the brain. Cells were mostly GABA+ and parvalbumin+; field excitatory postsynaptic potentials in CA1 induced by stimulation of Schaffer collaterals were smaller in transplanted animals. The authors concluded that intravenously transplanted human NSC suppress spontaneous recurrent seizures. Using the same model Costa-Ferro et al. (2010) evaluated the therapeutic potential of bone marrow mononuclear cells (BMC) obtained from transgenic mice. BMC cells have been reported to stimulate endogenous glial or neural stem cells, reduce neuronal apoptosis and neurodegeneration, modulate inflammatory responses, release trophic factors and cytokines involved in tissue repair and regeneration, and promote self-repair mechanisms in the brain (Costa-Ferro et al., 2010). Ninety-min after pilorcarpine-induced SE the animals received BMC or saline only via the tail-vain. By 15 days after transplantation, none of the BMC transplanted animals showed SRMS, while all saline-treated animals did; 120 days later only $25 \%$ of transplanted animals showed SRMS with a lower frequency and duration than control 
animals. Transplants attenuated cell loss in the hippocampus and BMC were found distributed in the brain of pilocarpine-treated recipient animals. In addition, long-term potentiation was preserved in the transplanted animals compared to pilocarpine-treated non-transplanted animals. The authors suggested that BMC could prevent the development of chronic seizures, reduce neuronal loss, and influence the reorganization of the hippocampal network.

Maisano et al., (2009) have also used ES-derived NSC in animal models of epilepsy, and have transplanted the YC5 mouse ES line into the CA3 region of the hippocampus one week after kainic acid or pilocarpine administration. The NSC expressed immature stem cell markers shortly after transplantation; with longer survival time (4-8 weeks) cells in the kainic acid model some cells expressed an early marker of granule neurons (Prox1). Eight weeks after transplantation many grafted neurons received synaptophysin-positive synaptic terminals, suggesting their integration into the host hippocampus. The same group used human NSC and observed similar results after transplantation into the kainate-lesioned brain (In: Maisano, et al., 2009). The cells migrated to the upper blade of the dentate gyrus only in mice that had experienced seizures, and expressed neuroblast markers (doubleclecortin, PSA-NCAM). Mouse but not human NSC formed tetrocarcinomas when transplanted into the mouse hippocampus. More recently, the same group has made electrophysiological recordings one month after transplantation into the dentate gyrus in kainate-treated mice. Their results showed that the cells have normal electrophysiological properties, receive syaptic inputs, and have the ability to fire spontaneous potentials. In their 2009 paper, Maisano et al. suggest the use of protocols to enrich for GABAergic precursors, based on the expression of glutamic-acid decarboxylase-67 (GAD67); they suggest the use of conditioned media, gene transfection of transcriptional factors, or sequential treatment with growth factors and molecules to guide progenitor cells toward GABAergic lineages.

In a recent critical review (Shetty \& Hattiangady, 2007) the authors state that there is no evidence in support of using stem cells in the treatment of temporal lobe epilepsy yet, although they acknowledge that the field is still in its initial stage of development. This conclusion is still valid at present. Among the strategies that Shetty and Hattiangady (2007) suggest for further advance in the field, two of them are particularly relevant for theme of the present review. First, is the need for rigorous analyses of the efficacy of grafts of ES cells or NSC placed into the hippocampus after the onset of chronic epilepsy for suppressing seizures as well as learning and memory deficits. In particular, the question of the duration of the suppressive effects is particularly relevant, because as can be gathered from the evidence presented above, the grafts of either fetal tissue or NSC have been evaluated for relatively short periods. These analyses should include evidence for the long-term survival of the grafts, and the differentiation of the cells in these grafts into functional principal hippocampal neurons, or GABA-ergic interneurons. Second, is the need for evaluating combination therapy, i.e., NSC or ES cells transplants and delivery of anticonvulsant compounds into the hippocampus during chronic epilepsy. As these authors suggest, this strategy might result in significant seizure suppressing effects. Finally, it should be emphasized that studies using fetal tissue and NSC transplants must include adequate control groups so that the effects of the grafts can be unequivocally attributed to the particular cell type or compound being tested. 


\begin{tabular}{|c|c|c|c|c|}
\hline Cell type & Model & $\begin{array}{l}\text { Site of } \\
\text { transplant }\end{array}$ & $\begin{array}{l}\text { Behavioral effects } \\
\text { Histological } \\
\text { findings }\end{array}$ & Reference \\
\hline $\begin{array}{l}\begin{array}{l}\text { Noradrenergic } \\
\text { (locus coeruleus, } \\
\text { E13-14) }\end{array} \\
\end{array}$ & $\begin{array}{l}\text { NA-depleted } \\
\text { rats; kindling 6- } \\
11 \text { months after } \\
\text { transplant. }\end{array}$ & Hippocampus & $\begin{array}{l}\text { Delayed onset and } \\
\text { retarded } \\
\text { progression of } \\
\text { kindling; } \\
\text { correlated with } \\
\text { neuron survival }\end{array}$ & Barry et al., 1987 \\
\hline $\begin{array}{l}\begin{array}{l}\text { Noradrenergic } \\
\text { (locus coeruleus, } \\
\text { E13-14) }\end{array} \\
\end{array}$ & $\begin{array}{l}\text { NA-depleted } \\
\text { rats; kindling 2-3 } \\
\text { months after } \\
\text { transplant. }\end{array}$ & $\begin{array}{l}\text { Amygdala- } \\
\text { pririform } \\
\text { cortex }\end{array}$ & $\begin{array}{l}\text { Delayed onset and } \\
\text { retarded } \\
\text { progression of } \\
\text { kindling. }\end{array}$ & Barry et al., 1989 \\
\hline $\begin{array}{l}\begin{array}{l}\text { Noradrenergic } \\
\text { (locus coeruleus, } \\
\text { E13-14) }\end{array} \\
\end{array}$ & $\begin{array}{l}\text { NA-depleted } \\
\text { rats; kindling } 3 \\
\text { months after } \\
\text { transplant, then } \\
\text { midrodialysis. }\end{array}$ & Hippocampus & $\begin{array}{l}\text { Retarded } \\
\text { progression of } \\
\text { kindling; restored } \\
\text { basal and seizure- } \\
\text { induced } \\
\text { extracellular } \\
\text { noradrenaline } \\
\text { levels in } \\
\text { hippocampus, } \\
\text { cells } \\
\text { immunopositive } \\
\text { for tyrosine } \\
\text { hydroxylase. }\end{array}$ & $\begin{array}{l}\text { Bengzon et al., } \\
1991\end{array}$ \\
\hline $\begin{array}{l}\text { GABAergic } \\
\text { (ganglionic } \\
\text { eminence, E16) }\end{array}$ & $\begin{array}{l}\text { Ibotenic acid } \\
\text { lesioned } \\
\text { animals; } \\
\text { pilocarpine } \\
\text { administration } 1 \\
\text { month after } \\
\text { transplant. }\end{array}$ & \begin{tabular}{|l|} 
Substantia \\
nigra reticulata
\end{tabular} & $\begin{array}{l}\text { Reduced } \\
\text { occurrence of } \\
\text { motor limbic } \\
\text { seizures, and } \\
\text { intensity score; } \\
\text { grafts localized in } \\
\text { the substantia } \\
\text { nigra. }\end{array}$ & Fine et al., 1990 \\
\hline $\begin{array}{l}\text { GABAergic } \\
\text { (ganglionic } \\
\text { eminence E14) }\end{array}$ & $\begin{array}{l}\text { Transplanted } \\
\text { after fully } \\
\text { kindled. }\end{array}$ & $\begin{array}{l}\text { Substantia } \\
\text { nigra reticulata }\end{array}$ & $\begin{array}{l}\text { Increased } \\
\text { afterdischarge } \\
\text { threshold, } \\
\text { decreased } \\
\text { severity; short- } \\
\text { lasting effects. } \\
\end{array}$ & $\begin{array}{l}\text { Löscher et al., } \\
1998\end{array}$ \\
\hline $\begin{array}{l}\text { GABAergic } \\
\text { (lateral } \\
\text { ganglionic } \\
\text { eminence, E15) }\end{array}$ & $\begin{array}{l}\text { KA-induced SE; } \\
\text { transplanted } 4 \\
\text { days after SE ; } \\
\text { evaluated } 9-12 \\
\text { months after SE. }\end{array}$ & Hippocampus & $\begin{array}{l}\text { Reduced number } \\
\text { of SRMS; } \\
\text { differentiated into } \\
\text { GABAergic cells. }\end{array}$ & $\begin{array}{l}\text { Hattiangady et } \\
\text { al., } 2008\end{array}$ \\
\hline
\end{tabular}

Table 1. Studies using transplants of fetal tissue and neural stem cells into the brain in animal epilepsy models. 


\begin{tabular}{|c|c|c|c|c|}
\hline Cell type & Model & $\begin{array}{l}\text { Site of } \\
\text { transplant }\end{array}$ & \begin{tabular}{|l|} 
Behavioral effects \\
Histological \\
findings
\end{tabular} & Reference \\
\hline $\begin{array}{l}\text { Hipocampal } \\
\text { cells (E19) }\end{array}$ & $\begin{array}{l}\text { KA-induced SE; } \\
\text { transplanted after } \\
\text { showing } \\
\text { spontaneous motor } \\
\text { seizures; evaluated } \\
2 \text { monts after } \\
\text { grafting. }\end{array}$ & Hippocampus & $\begin{array}{l}\text { Reduced number of } \\
\text { SRMS; greater } \\
\text { survival of neurons } \\
\text { and GABA } \\
\text { interneurons in } \\
\text { hippocampi if } \\
\text { pretreated with } \\
\text { neurotrophic } \\
\text { factors and caspase } \\
\text { inhibitor. }\end{array}$ & Rao et al., 2007 \\
\hline $\begin{array}{l}\text { Neural stem } \\
\text { cells (medial } \\
\text { ganglionic } \\
\text { eminence, } \\
\text { E14) }\end{array}$ & $\begin{array}{l}\text { KA-induced SE; } \\
\text { transplanted after } \\
\text { showing } \\
\text { spontaneous motor } \\
\text { seizures; evaluated } \\
3 \text { months after } \\
\text { grafting. } \\
\text { Evaluation of } \\
\text { seizures and } \\
\text { learning and } \\
\text { memory. }\end{array}$ & Hippocampus & $\begin{array}{l}\text { Reduced frequency } \\
\text { and duration of } \\
\text { SRMS; no } \\
\text { improvement in } \\
\text { cognitive function; } \\
\text { differentiation into } \\
\text { neurons (some } \\
\text { GABA+), astrocytes } \\
\text { and } \\
\text { oligodendrocyte } \\
\text { progenitors, } \\
\text { restored GDNF in } \\
\text { hippocampus. }\end{array}$ & $\begin{array}{l}\text { Waldau et al., } \\
2010\end{array}$ \\
\hline $\begin{array}{l}\text { Adenosine- } \\
\text { releasing ES } \\
\text { cells } \\
\text { encapsulated } \\
\text { in polymer } \\
\text { membranes }\end{array}$ & $\begin{array}{l}\text { Kindling model, } \\
\text { evaluated } 3 \text { days } \\
\text { after grafting until } \\
7 \text { days. }\end{array}$ & $\begin{array}{l}\text { Lateral } \\
\text { ventricle }\end{array}$ & \begin{tabular}{|l|} 
Transient \\
protection from \\
convulsive seizures \\
and reduction of \\
afterdischarge \\
activity in EEG \\
recordings.
\end{tabular} & $\begin{array}{l}\text { Güttinger et al., } \\
2005\end{array}$ \\
\hline $\begin{array}{l}\text { NSC from } \\
\text { Adk-/- or } \\
A d k+/+\end{array}$ & $\begin{array}{l}\text { Kindling model, } \\
\text { grafted before } \\
\text { kindling; evaluated } \\
\text { for } 3 \text { weeks. }\end{array}$ & Hippocampus & \begin{tabular}{|l|} 
NSC from Adk-/- \\
retarded \\
epileptogenesis, \\
prevented \\
occurrence of \\
generalized \\
seizures. Dense \\
cellular transplants, \\
some cells NeuN+. \\
\end{tabular} & Li et al., 2007 \\
\hline
\end{tabular}

Table 1. Studies using transplants of fetal tissue and neural stem cells into the brain in animal epilepsy models. (continuation) 


\begin{tabular}{|c|c|c|c|c|}
\hline Cell type & Model & $\begin{array}{l}\text { Site of } \\
\text { transplant }\end{array}$ & $\begin{array}{l}\text { Behavioral effects } \\
\text { Histological } \\
\text { findings }\end{array}$ & Reference \\
\hline NSC & \begin{tabular}{|l} 
Pilocarpine \\
treatment, \\
transplanted one \\
month later, \\
evaluated 13-34 \\
days after \\
transplantation. \\
\end{tabular} & Hippocampus & $\begin{array}{l}\text { NSC showed } \\
\text { intrinsic and } \\
\text { synaptic neuronal } \\
\text { properties, receive } \\
\text { excitatory and } \\
\text { inhibitory inputs. }\end{array}$ & $\begin{array}{l}\text { Rüschenschmidt } \\
\text { et al., } 2005\end{array}$ \\
\hline NSC & $\begin{array}{l}\text { KA-induced SE, } \\
\text { transplanted one } \\
\text { week later, EEG } \\
\text { recorded } 3 \text { weeks } \\
\text { after } \\
\text { transplantation. }\end{array}$ & \begin{tabular}{|l|} 
Hippocampus, \\
with or \\
without EPO \\
(icv)
\end{tabular} & $\begin{array}{l}\text { Reduced frequency } \\
\text { of abnormal spikes; } \\
\text { attenuates aberrant } \\
\text { mossy fiber } \\
\text { sprouting; } \\
\text { differentiated into } \\
\text { GFAP+ astrocytes; } \\
\text { EPO enhanced } \\
\text { survival. }\end{array}$ & Jing et al., 2009 \\
\hline hNSC & \begin{tabular}{|l} 
Pilocarpine- \\
induced SE, 24h \\
later cells injected; 6 \\
weeks later, \\
histology or \\
electrophysiological \\
recordings of \\
hippocampal slices. \\
\end{tabular} & \begin{tabular}{|l|} 
Intravenous \\
administration, \\
tail vein
\end{tabular} & $\begin{array}{l}\text { Reduction in } \\
\text { convulsive seizures; } \\
\text { smaller fEPSP in } \\
\text { CA1; labelled cells } \\
\text { found in } \\
\text { hippocampus and } \\
\text { other brain areas, no } \\
\text { tumor formation. } \\
\end{array}$ & Chu et al., 2004 \\
\hline $\mathrm{BMC}$ & $\begin{array}{l}\text { Pilocarpine- } \\
\text { induced SE, } 90 \text { min } \\
\text { later cells injected; } \\
\text { evaluated } 15 \text { and } \\
120 \text { days later. }\end{array}$ & \begin{tabular}{|l|} 
Intravenous \\
administration, \\
tail vein
\end{tabular} & $\begin{array}{l}\text { Short-term } \\
\text { suppressed SRMS; } \\
\text { long-term only 25\% } \\
\text { animals with BMC } \\
\text { showed SRMS of } \\
\text { lower frequency and } \\
\text { duration than } \\
\text { controls; attenuated } \\
\text { cell loss in the } \\
\text { hippocampus; long- } \\
\text { term potentiation } \\
\text { preserved. }\end{array}$ & $\begin{array}{l}\text { Costa-Ferro } \\
\text { et al., } 2010\end{array}$ \\
\hline
\end{tabular}

Table 1. Studies using transplants of fetal tissue and neural stem cells into the brain in animal epilepsy models.(continuation) 


\begin{tabular}{|c|c|c|c|c|}
\hline Cell type & Model & $\begin{array}{l}\text { Site of } \\
\text { transplant }\end{array}$ & $\begin{array}{l}\text { Behavioral effects } \\
\text { Histological } \\
\text { findings }\end{array}$ & Reference \\
\hline $\begin{array}{l}\text { NSC and } \\
\text { hNSC }\end{array}$ & $\begin{array}{l}\text { KA or pilocarpine } \\
\text { administration, } \\
\text { transplanted one } \\
\text { week later. }\end{array}$ & $\begin{array}{l}\text { Hippocampus } \\
\text { CA3 }\end{array}$ & $\begin{array}{l}\text { Expression of } \\
\text { immature cell } \\
\text { makers, and of } \\
\text { granule cells after } \\
\text { longer survival } \\
\text { times. Inputs of } \\
\text { synaptohpysin+ } \\
\text { synaptic terminals. } \\
\text { Mouse NSC formed } \\
\text { teratomas. hNSC } \\
\text { migrated to dentate } \\
\text { gyrus. Neuronal } \\
\text { electrophysiological } \\
\text { characteristics. }\end{array}$ & $\begin{array}{l}\text { Maisano et al., } \\
2009\end{array}$ \\
\hline
\end{tabular}

Table 1. Studies using transplants of fetal tissue and neural stem cells into the brain in animal epilepsy models. (continuation)

$A d k$ : adenosine kinase, enzyme that phosphorylates adenosine in eukaryotes; BMC: bone marrow mononuclear cells; CA: Cornu Ammonis; EEG: electroencephalogram; EPO: erythropoietin; ES: embryonic stem cells; fEPSP: field excitatory postsynaptic potentials; GABA: gamma-aminobutyric acid; GDNF: glial-derived neurotrophic factor; GFAP: glial fibrillary acidic protein; hNSC: human neural stem cells; icv: intracerebroventricular administration; KA: kainic acid; NA: noradrenaline; NeuN: a mature neuronal marker; NSC: neural stem cells; SE: status epilepticus; SRMS: spontaneous recurrent motor seizures.

\section{Preclinical studies using cell transplants of cell lines in animal models of epilepsy}

The use of fetal tissue for transplantation involves ethical and technical issues that can be circumvented by using cell lines. The advances in molecular biology techniques provided the means to immortalize and genetically modifiy cells to produce specific growth factors, and enzymes. One example of a cell line with intrinsic GABAergic properties is the clone M213-20, derived from the ganglionic eminence of E14-15 Sprague-Dawley rats. This cell line was obtained by immortalizing neuroblasts using the temperature sensitive allele (A58) of the SV40 large T antigen, and was found to have some GABAergic characteristics (Giordano et al., 1993; 1996). This cell line was further modified by transfection with the hGAD $_{67}$ cDNA by means of a plasmid based on the Epstein-Barr virus. From the clones obtained, one was selected, the M213-2O CL-4 that synthesizes and releases significantly more GABA than the parent cell line (Conejero-Goldberg et al., 2000), reuptakes GABA, responds to glutamate, presents calcium transients, and releases the neurotransmitter in a calcium-dependent manner (Mejia-Toiber et al., 2010). This cell line when transplanted into the inferior colliculus increases the latency for audiogenic seizures (Ross, et al., 2002); it increases the latency for tonic-clonic seizures induced by kainic acid, and decreases their severity when transplanted into the SNr (Castillo et al., 2006) (Table 2). In a more recent 


\begin{tabular}{|c|c|c|c|c|}
\hline Cell type & Model & \begin{tabular}{|l} 
Site of \\
transplant
\end{tabular} & \begin{tabular}{|l} 
Behavioral effects \\
Histological findings
\end{tabular} & Reference \\
\hline M213-2O CL-4 & $\begin{array}{l}\text { Audiogenic } \\
\text { seizures. }\end{array}$ & $\begin{array}{l}\text { Inferior } \\
\text { colliculus }\end{array}$ & $\begin{array}{l}\text { Inccreases latency to } \\
\text { audiogenic seizures. }\end{array}$ & $\begin{array}{l}\text { Ross } \\
\text { et al., } 2002\end{array}$ \\
\hline M213-2O CL-4 & $\begin{array}{l}\text { KA-induced SE; } \\
\text { transplanted } 8 \\
\text { weeks before. }\end{array}$ & $\begin{array}{l}\text { Substantia } \\
\text { nigra } \\
\text { reticulata }\end{array}$ & $\begin{array}{l}\text { Increases latency for } \\
\text { tonic-clonic seizures, } \\
\text { reduces their intensity. }\end{array}$ & $\begin{array}{l}\text { Castillo } \\
\text { et al., } 2006\end{array}$ \\
\hline M213-2O CL-4 & $\begin{array}{l}\text { KA-induced } \\
\text { SRMS; evaluated } \\
\text { at } 4 \text { and } 12 \text { weeks } \\
\text { after } \\
\text { transplantation. }\end{array}$ & $\begin{array}{l}\text { Substantia } \\
\text { nigra } \\
\text { reticulata }\end{array}$ & $\begin{array}{l}\text { Reduces the percentage } \\
\text { of animals showing } \\
\text { SRMS; longer survival } \\
\text { times for transplanted } \\
\text { rats, GABA content } \\
\text { increased in area of graft. }\end{array}$ & $\begin{array}{l}\text { Castillo } \\
\text { et al., } 2008\end{array}$ \\
\hline M213-2O CL-4 & $\begin{array}{l}\text { Kindling model; } \\
\text { evaluated for } 8 \\
\text { weeks. }\end{array}$ & $\begin{array}{l}\text { Substantia } \\
\text { nigra } \\
\text { reticulata }\end{array}$ & $\begin{array}{l}\text { No improvement; strong } \\
\text { tissue reaction in } \\
\text { kindled animals. }\end{array}$ & $\begin{array}{l}\text { Nolte } \\
\text { et al., } 2008\end{array}$ \\
\hline M213-2O CL-4 & $\begin{array}{l}\text { Genetic model of } \\
\text { absence seizures } \\
\text { (GAERS) }\end{array}$ & $\begin{array}{l}\text { Substantia } \\
\text { nigra } \\
\text { reticulata }\end{array}$ & No reduction in seizures. & $\begin{array}{l}\text { Castillo } \\
\text { et al., } 2010\end{array}$ \\
\hline $\begin{array}{l}\text { Cortical cell } \\
\text { line CN1.4 } \\
\text { with } \\
\text { GAD65cDNA }\end{array}$ & $\begin{array}{l}\text { Transplanted, } \\
\text { then kindled in } \\
\text { amygdala }\end{array}$ & $\begin{array}{l}\text { Piriform } \\
\text { cortex }\end{array}$ & $\begin{array}{l}\text { Increases in pre-kindling } \\
\text { partial seizure threshold, } \\
\text { and increased latency to } \\
\text { the first generalized } \\
\text { seizure during kindling. } \\
\text { GAD65 long-term } \\
\text { expression. }\end{array}$ & $\begin{array}{l}\text { Gernert } \\
\text { et al., } 2002\end{array}$ \\
\hline $\begin{array}{l}\text { Cortical cell } \\
\text { line CN1.4 } \\
\text { with } \\
\text { GAD65cDNA }\end{array}$ & $\begin{array}{l}\text { Pilocarpine- } \\
\text { induced SE, then } \\
\text { transplanted, } \\
\text { evaluated } 3 \text { days } \\
\text { and 7-8 days after } \\
\text { surgery }\end{array}$ & $\begin{array}{l}\text { Substantia } \\
\text { nigra } \\
\text { reticulata }\end{array}$ & $\begin{array}{l}\text { Fewer SRMS, integration } \\
\text { into the host, effect } \\
\text { diminished if transgene } \\
\text { is suppressed. }\end{array}$ & \begin{tabular}{|l|} 
Thompson \& \\
Suchomelova, \\
2004
\end{tabular} \\
\hline $\begin{array}{l}\text { Cortical cell } \\
\text { line CN1.4 } \\
\text { with } \\
\text { GAD65cDNA }\end{array}$ & $\begin{array}{l}\text { Transplanted, } \\
\text { then hippocampal } \\
\text { stimulation; } \\
\text { transplanted, then } \\
\text { kindling in } \\
\text { entorhinal cortex }\end{array}$ & $\begin{array}{l}\text { Dentate } \\
\text { gyrus }\end{array}$ & $\begin{array}{l}\text { Increased after discharge } \\
\text { threshold; longer latency } \\
\text { to first generalized } \\
\text { seizure. }\end{array}$ & $\begin{array}{l}\text { Thompson, } \\
2005\end{array}$ \\
\hline $\begin{array}{l}\text { GDNF cells } \\
\text { encapsulated } \\
\text { in semi- } \\
\text { permeable } \\
\text { membrane }\end{array}$ & $\begin{array}{l}\text { Kindling, then } \\
\text { implanted, then } \\
\text { rekindled } 4 \text { weeks } \\
\text { later. }\end{array}$ & \begin{tabular}{|l|} 
Ventral \\
hippcampus
\end{tabular} & $\begin{array}{l}\text { Lower levels of GDNF } \\
\text { reduced duration of } \\
\text { afterdischarges, and } \\
\text { seizure severity. }\end{array}$ & $\begin{array}{l}\text { Kanter- } \\
\text { Schlifke } \\
\text { et al., } 2009\end{array}$ \\
\hline
\end{tabular}

GAD: glutamate decarboxylase, the synthetic enzyme for the neurotransmitter GABA; GAERS: Genetic Absence Epilepsy Rat from Strasbourg; GDNF: glial derived neurotrophic factor; KA: kainic acid; SRMS: spontaneous recurrent motor seizures.

Table 2. Studies using cell lines in animal models of epilepsy. 
study, it was found that intranigral transplants of this GABAergic cell line decrease the percentage of rats showing spontaneous seizures induced by kainic acid, at 4 and 12 weeks after transplantation into the SNr (Castillo et al., 2008) (Table 2). Beneficial effects are not observed in all animal models using nigral transplants of cell line M213-2O CL-4. In Wistar rats in a model of kindling a strong immune reaction was observed (Nolte et al., 2008). This strong immune reaction was only observed in kindled animals transplanted with cell line M213-CL-4. In another study, transplants of this cell line did not reduce absence seizures in the genetic epilepsy model of the Strasbourg rats (GAERS) (Castillo et al., 2010).

A different cell line, $\mathrm{CN}$ 1.4, contains $\mathrm{GAD}_{65}$ cDNA the other enzyme involved in the synthesis of GABA. The vector used to generate this cell line, produces two gene products, a tetracycline-responsive transactivator (tTA) and neomycin phosphotransferase (Thompson et al., 2000), thus, when doxycycline is present tTA cannot bind to the promoter, and cannot direct transcription (Thompson 2005). Transplants of this cell line into the SNr reduce susceptibility to crisis in the model of kindling and reduce the number of epileptiform spikes in lithium pilocarpine-induced seizures (Gernert et al., 2002; Thompson \& Suchomelova, 2004) (Table 1). In the entorhinal cortex-kindling model Thomspon (2005) observed increased GABA levels in the hippocampus 3 and 10 days after transplantation of this cell line. They found that behavioral seizures and afterdischarges were reduced only in the animals with transplants of the GABA cells. GABA levels in vivo and in vitro decreased when the cells were treated with doxycycline, and so did the behavioral effects.

In a recent study a genetically modified cell line that synthesizes and releases the glial derived neurotrophic factor (GDNF) was encapsulated in a semipermeable membrane and transplanted into the hippocampus. Those animals transplanted with capsules that released a moderate amount of GDNF showed a decrease in the severity of the seizures and in the duration of the afterdischarge (Kanter-Schlifke, et al., 2009).

At present, there are no other cell lines that have been tested in animal models of epilepsy. These studies taken together, have demonstrated that increasing levels of the inhibitory transmitter GABA into the $\mathrm{SNr}$, hippocampus, amygdala, piriform cortex, or inferior colliculus, does reduce seizures in a variety of animal models. The challenge is to take this knowledge and transform it into a therapeutic strategy that may be successful in the clinical setting.

\section{Clinical studies using cell transplants: lessons from Parkinson's disease}

Preclinical proof-of-concept studies are necessary to show that transplanted cells can survive, differentiate, integrate, and exert functional effects in the animal model of choice. They are also necessary to find the shortcomings and undesirable side effects of these procedures. However, animal models can only go so far in providing information about the use of neural transplants in the clinical setting. These experimental models have evident shortcomings because they cannot reproduce the particular environment of the diseased brain, the progression of the illness, or the survival time of the host, among others. In this sense, only clinical studies can definitively answer the question of whether or not transplants can reduce the symptoms or slow the progression of the disease, and for how long they may give the patient an overall better quality of life.

The clinical studies using neural and adrenal transplants in Parkinson's disease (PD), can provide with a wealth of information regarding the potential of this procedure, its shortcomings, and the factors that still need to be resolved. PD is a progressive neurological 
disorder characterized by tremor, rigidity, and slowness of movements, associated with cell loss in the substantia nigra, pars compacta, and other brain structures (Tolosa et al., 2006). Substantia nigra pars compacta cells (SNc) produce and release dopamine (DA) in the caudate nucleus and putamen, a neurotransmitter involved in motor behavior. In addition to loss of DA cells in the nigra, other histopahtological signs include the presence of dystrophic neurites, and Lewy body inclusions in the surviving DA cells. Lewy bodies are $\alpha$-synuclein and ubiquitin-containing intracytoplasmic inclusions (Kövari et al., 2009). PD was the first neurological disorder in which neural transplants were used. The source of tissue for transplantation initially were adrenal medulla chromaffin cells, since they produce and release substantial quantities of catecholamines (Drucker-Colin \& Verdugo-Diaz, 2004). In 1990, Freed et al., wrote a thorough review about the status of intracerebral adrenal medulla grafts, they reviewed the results of about ten of the early studies of adrenal grafts for the treatment of Parkinson's disease. Two primary methods of autotransplantation were used then, the first involved transplantation of adrenal medulla into the striatum by stereotaxic injection; the other involved transplantation of the adrenal tissue to cavities in the wall of the lateral ventricle. The conclusions of this review indicated that intrastriatal adrenal medulla grafts caused only a transient improvement, whereas intraventricular grafts appeared to have a more lasting effect. The degree of improvement, though, differed among studies, and ranged from substantial to modest. The major improvements had to do with increases in duration of "on" times, that is the time when the medication is having an effect, and the patient can move. In Parkinson's disease there are fluctuations in the response to the medication, this periods are known as "on", and "off". Great variability was observed from patient to patient, the majority improved only slightly and a few had greater effects. The evidence also suggested that the creation of a cavity on the wall of the ventricle could enhance the trophic effects of the grafts. In this review, the authors advocated the use of quantitative objective measures of motor function, in addition to rating scales only; the inclusion of control trials involving comparisons between patients receiving grafts and controls, non-treated groups, or groups receiving other treatments. They concluded that when adrenal medulla grafts survive the functional effects could be the result of release of dopamine, and possibly other substances. When they do not survive, the functional effects must be attributed to the host brain reaction to injury or to the release of chemical substances with trophic effects outlasting their production, or the production of substances by surviving non-chromaffin cells. At that time, postmortem studies in human patients showed lack of tyrosine hydroxylase $(\mathrm{TH})$ positive cells (tyrosine hydroxylase is the rate-limiting enzyme in the synthesis of dopamine and norepinephrine) but there was not enough data to correlate the clinical outcome to the presence or absence of TH positive cells. In a later review of the field, Freed (1993) addressed the results of fetal mesencephalic transplants in human patients with Parkinson's disease. These studies reported clinical improvement over the course of several months after transplantation. Early changes were, according to the author, qualitatively similar to those observed after adrenal grafts. Positron emission tomography (PET) studies indicated increased 6-[18F]-fluoro-L-dopa (FD) uptake in the region of the graft. FD is a marker that allows monitoring of the uptake and decarboxylation of FD to fluorodopamine (FDA), and the subsequent storage of FDA in synaptic vesicles, thus giving an indication of pre-synaptic DA function (Au et al., 2005). At that time, no controlled studies on mesencephalic grafts had taken place. A decade later, Roitberg et al. (2000) reviewed the clinical studies using neural grafting for Parkinson's and 
Huntington's disease. At that time more than 150 procedures for fetal transplantation in Parkinson's disease had been reported over the world. The range of clinical benefits was variable, some patients showed improvement in terms of reductions in "off" periods, reduction of medication, increase in FD uptake in the grafted areas, improvement in activities of daily living scores, while others showed no improvement, and some patients developed dyskinesia contralateral to the implanted side. Some degree of clinical improvement had been observed even 60 months after transplantation. In terms of anatomical characteristics, the authors indicated that $\mathrm{TH}$ positive neurons were identified in the graft of a patient that died 18 months postoperatively from an event unrelated to the surgery. Electron microscopic studies indicated synapses between transplanted TH cells and host cells in the putamen.

Several technical improvements were made in the decade between 1990 and 2000 that could account for better outcome of grafting procedures. Among them were a more favorable donor age, considered to be when dopaminergic cells first appear in the subventricular zone just prior to neuritic process extension. Grafts of fetal tissue older than 9 weeks gestational age did not show significant clinical effects or survival of TH positive cells. Another issue was time between obtaining the tissue and grafting, studies showing clinical benefits used tissue within 24-48 h of tissue acquisition (Roitberg et al., 2000). An advantage of solid versus suspension grafts was suggested, and the number of transplanted cells was also important. Apparently the greater the number of replacement cells, the better the clinical effect. Another factor was the location of the transplant, whether caudate nucleus or putamen, Roitberg et al., (2000) suggested that the putamen was a better site for implantation, and that greater improvement could be achieved by bilateral transplants. Importantly, transplants of $\mathrm{TH}+$ cells had been shown to extend neuritic processes up to 5-7 $\mathrm{mm}$ from the grafted site, although complete reversal of symptoms had not been achieved in spite of this innervation pattern. The need for immunosuppression had not been firmly established.

In the first decade of this century, the results of two double-blind controlled trials were published. The first in 2001 by Freed et al., reported on the results of operations on 40 patients that began in 1995 and ended in 1998, and included a sham group, that later had the option of receiving the graft. The results of the study were rather sobering, motor aspects improved $18 \%$ in the transplanted group as a whole, and $34 \%$, if only patients 60 years of age or younger were considered. Rigidity and bradykinesia were reduced in the younger groups, but no improvement on tremor was observed. FD indicated an increase in radionuclide uptake in the putamen of the transplanted group, without changes in the sham group. One 66-year-old patient died of causes unrelated to the surgical procedure seven months after transplantation, and the postmortem analysis of the brain indicated the presence of $\mathrm{TH}+$ cells with outgrowth of 2-3 mm, without Lewy bodies. Postmortem analysis of the brain of another patient (a 68-year-old man who died three years after the transplantation procedure, also from causes unrelated to the surgery) showed surviving dopamine cells in the tissue, with outgrowth that extended the full width of the putamen. PET-FD had shown 100\% improvement in uptake over baseline measures. On a three-year follow-up, there was a $38 \%$ improvement in the younger group of patients and $14 \%$ of older patients, five patients developed dystonia and dyskinesia. The authors concluded that their results were similar to those of open studies. In 2003 the results of another double-blind controlled study were reported (Olanow et al., 2003) with similar results. Comparisons 
between placebo and transplanted groups were not significant even though striatal FD uptake was significantly increased in the transplanted groups, and survival of dopamine neurons was observed at postmortem examination of five patients who died during the study from causes unrelated to the transplant. Number of surviving $\mathrm{TH}+$ cells ranged from $30,000-120,000$ per side depending if the patient had received a one-donor or a four-donor graft. Activated microglia and immune reactivity was observed in the transplanted group in and around the region of the graft. In addition $56 \%$ of transplanted patients developed dyskinesia. The authors concluded that fetal nigral transplantation was not recommended at that time. Goetz et al. (2005) reached a similar conclusion after an evidence-based medical review update on the various treatments for PD from 2001-2004. On the basis of their analyses, the authors concluded that fetal mesencephalic grafts were non-efficacious meaning that evidence showed that the intervention did not have a positive side effect on studied outcomes.

In 2005 Piccini et al., addressed some of the issues pertaining to the clinical outcome after neural transplantation in PD. On the basis of their results with nine patients from a full series of fourteen grafted PD patients, they suggested that clinical outcome is best when more than 100,000 DA neurons are grafted and at least $1 / 3$ to $1 / 2$ of the putamen is reinnervated. This degree of innervation corresponds to $50 \%$ of normal FD uptake, although as indicated in the previous studies it does not always match with the level of clinical improvement. This study contributed importantly to the discussion of the mechanisms that underlie the development of dyskinesia, they found no association between graft-induced dyskinesia and DA release under basal or methamphetamine administration. They also concluded that grafts in the putamen do not protect intrinsic DA neurons in the nigra from degenerating, that a better outcome can be found in patients in whom the degeneration of the intrinsic DA system was confined to areas reached by the graft, and that immunosuppression could be stopped without compromising the survival of the grafts or the clinical improvement. From these studies it became clear that the response to the grafts varies between individuals, that factors such as tissue handling and storage, immunosupressive treatment, and patient selection needs to be improved, thus this type of therapy requires that it be tailored individually to each patient (Winkler et al., 2008).

In a follow-up to the study published by Freed et al. in 2001, Ma et al. (2009) reported the results obtained two and four years after transplantation. Interestingly the motor scores of the transplanted patients improved $25 \%$ in the 4 -year evaluation in the group as a whole. In addition, differences found previously between younger and older patients, and men and women did not persist over time. Increased FD uptake was found in both hemispheres, and it was correlated to clinical outcome. They also observed that better outcome was associated with the degree of FD uptake present preoperatively in the ventrorostral putamen. In the same region they detected progressive loss over the 4-year period, suggesting ongoing neurodegeneration.

Recently, various studies have addressed the issue of the presence of Lewy bodies, and activated microglia in the grafts of patients that received transplants a decade or more before (Li et al., 2008; Kordower et al., 2008a, 2008b). In these studies it was suggested that the presence of Lewy bodies could indicate that the microenvironment of the host brain may affect DA neurons, or that somehow the pathological process can spread to the grafted cells, although the presence of Lewy bodies may not affect the functional effects of the grafts. Importantly, these studies also found survival of $\mathrm{TH}+$ cells in the transplants. 
In contrast, Mendez et al. (2008) after evaluating the histopathological characteristics of 34, and 9-14 year-old transplants did not find Lewy bodies in the grafts. In this study, they reported that serotonin cells were present, and they suggested that the presence of this type of cell could be involved in the development of dyskinesia. Cooper et al., (2009) evaluated the histological evidence of the studies dealing with post-mortem cases of patients with neural transplants, and concluded that the presence of Lewy bodies could be related to the type of graft, solid tissue versus cell suspension, the former having resulted in greater microglial activation indicating an increased host inflammatory response that could have contributed to the development of PD-like pathology, and to accelerated aging in some transplants in PD patients. In the view of Cooper et al. (2009) the vast majority of transplanted neurons in the studies reviewed, remained healthy and continued to provide substantial clinical benefits for over a decade. They suggest that future studies should look into the use of pluripotent stem (iPS) cells as a source for donor cells. This technology could improve transplant quality and content, by providing sorted pure DA populations. A similar proposal has been expressed in other reviews on the future of cell and gene therapies for PD (Isacson \& Kordower, 2008; Wang et al., 2007; Li et al., 2007; Winkler et al., 2005).

In conclusion, the review of the studies of neural transplants in PD shows that this therapy has to be tailored to each patient, that issues such as the transplantation procedure, i.e., solid tissue grafts versus cell suspension grafts, location of the grafts, tissue handling and storage, age of donor, immunosuppression therapy, and patient selection in terms of age, gender, and degree of degeneration as evaluated by PET-FD uptake have to be taken into consideration. They have also shown that fetal grafts can survive for extended periods, and can improve the clinical status of some of the patients for a considerable length of time. However, it does not appear to be a therapeutic alternative suited for the majority of PD patients. The experience obtained in this regard, needs to be taken into consideration before proceeding to the use of cell transplants in epilepsy. Animal studies using models of epilepsy have provided valuable information about the functional effects of transplants however, a drawback of these studies is the duration of the effects; therefore alternatives such as the use of gene therapy are now being considered (Löscher et al., 2008).

\section{Closing remarks}

Advances in molecular and cell biology have now made it possible to immortalize neural cells, including stem cells, to replace lost cells or replenish the supply of selected molecules (Mejia-Toiber, in press) and have thus provided a new source for neural transplantation, one that could possibly be tailored to each patient. Although unquestionably promising and exciting, there are still some issues to be solved before these cells can be used routinely in the clinic. Several authors have voiced concerns similar to those expressed for transplants using fetal tissue (e.g., Allan et al., 2010; Kim et al., 2004; Li et al., 2008; Lindvall et al., 2004; Muller et al., 2006; Snyder et al., 2004; Storch et al., 2004). We have classified these concerns in two categories. The first one includes the negative effects of transplantation of stem cells into the brain. These include the immune rejection of the transplant, and the effects of prolonged immunosuppression. Other negative effects are the potential for tumor formation after differentiated ES are transplanted resulting either from residual proliferating ES cells or precursors, or by the epigenetic changes resulting from their manipulation and the 
presence of retroviral vectors. In the case of cell transplantation in PD there is also the concern for graft-induced dyskinesia (Allan et al., 2010).

The second category of concerns includes the need to tailor cell therapy to the pathology of interest. It must be considered if it would be preferable to transplant a homogeneous population, for example, neural cells, versus transplanting a mixed population including cells of glial lineage in order to favor their integration into the host's nervous system to promote functional recovery. Stem cells can provide the host environment with trophic and neuroprotective support to promote the recovery of endogenous cells, to mobilize host progenitors, and to favor inherent neurogenetic programs within the host, in addition to replacing host cells (Snyder et al., 2004). Furthermore, the reciprocal stem cell-host interaction needs to be taken into consideration, because the host environment may affect stem cell behavior by exposing these cells to factors related to the brain pathology of the host that may confer an invasive phenotype (Muller et al., 2006). Indeed, NSC and BMC have been shown to migrate to localized and also widespread lesions after transplantation (e.g., Costa-Ferro, 2010; Chu et al., 2004); at least three processes seem to influence this migratory behavior: inflammation, reactive astrocytosis, and angiogenesis (Muller et al., 2006).

Undoubtedly, all these developments from adrenal to fetal grafts, to the generation of NSC with specific characteristics have increased our knowledge about the neurologic disorders themselves, about the potential for regeneration and restoration of function that the brain has, about the effects of neurotrophic factors, and about brain development. New technical alternatives have been found, the use of stem cells, the possibility of induced PSC, and gene therapy. One should bear in mind that restoring lost functions by replacing damaged cells is not a trivial process if one considers the intricate relationships that exist among nerve cells, and that complex neural circuits underlie sensory, motor, and cognitive functions. After more than two decades of basic and clinical work in neural transplantation, it has become evident that in order to ensure long-term effects neural transplants need to do more than just supply the molecule of interest. However, the positive results obtained in the past together with the recent technical advances indicate that in the future we can expect that therapeutic alternatives will be available in the clinical setting to improve the quality of life of human patients.

\section{Acknowledgments}

This work was partially supported by CONACYT Grant No. 103907, and DGAPA-UNAM PAPIIT Grant No. 211709 to M. Giordano. The author thanks S. Mendoza, for assistance in the preparation of this manuscript.

\section{References}

Allan, L.E., Petit, G.H., \& Brundin, P. (2010). Cell transplantation in Parkinson's disease: problems and perspectives. Current Opinion in Neurology Vol.23, No.4, (August 2010), pp. 426-432, ISSN 1473-6551.

Au, W.L, Adams, F.R., Roitano, A.R., \& Stoessl, A.J. (2005). Parkinson's disease: in vivo assessment of disease progression using positron emission tomography. Molecular Brain Research, Vol.134, (November 2004), pp. 24-33, ISSN 0169-328X. 
Barberi, T., Klivenyi, P., Calingasan, N.Y., Lee, H., Kawamata, H., Loonam, K., Perrier, A.L., Bruses, J., Rubio, M.E., Topf, N., Tabar, V., Harrison, N.L., Beal, M.F., Moore, M.A. \& Studer, L. (2003). Neural subtype specification of fertilization and nuclear transfer embryonic stem cells and application in parkinsonian mice. Nature Biotechnology, Vol 21, No. 10, (Oct, 2003), pp. 1200-1207, ISSN 1087-0156.

Barry, D.I., Kikvadze, I., Brundin, P., Bolwig, T.G., Bjorklund, A. \& Lindvall, O. (1987). Grafted noradrenergic neurons suppress seizure development in kindling-induced epilepsy. Proceedings of the Nationall Academy of Science U S A, Vol. 84, No. 23, (December 1987), pp. 8712-8715, ISSN 0027-8424.

Barry, D.I., Wanscher, B., Kragh, J., Bolwig, T.G., Kokaia, M., Brundin, P., Bjorklund, A. \& Lindvall, O. (1989). Grafts of fetal locus coeruleus neurons in rat amygdala-piriform cortex suppress seizure development in hippocampal kindling. Experimental Neurology, Vol.106, No. 2, (November 1989), pp. 125-132, ISSN 0014-4886.

Bengzon, J., Brundin, P., Kalen, P., Kokaia, M. \& Lindvall, O. (1991). Host regulation of noradrenaline release from grafts of seizure-suppressant locus coeruleus neurons. Experimental Neurology, Vol.111, No. 1, (January 1991), pp. 49-54, ISSN 0014-4886.

Berg, A.T., Berkovic, S.F., Brodie, M.J., Buchhalter, J., Cross, J.H., van Emde Boas, W., Engel, J., French, J., Glauser, T.A., Mathern, G.W., Moshe, S.L., Nordli, D., Plouin, P. \& Scheffer, I.E. (2010). Revised terminology and concepts for organization of seizures and epilepsies: report of the ILAE Commission on Classification and Terminology, 2005-2009. Epilepsia, Vol.51, No. 4, (April 2010 ), pp. 676-685, ISSN 1528-1167.

Bjorklund, A. \& Stenevi, U. (1984). Intracerebral neural implants: neuronal replacement and reconstruction of damaged circuitries. Annual Review of Neuroscience, Vol.7 (March 1984), pp. 279-308, ISSN 0147-006X.

Carpenter, M.K., Inokuma, M.S., Denham, J., Mujtaba, T., Chiu, C.P. \& Rao, M.S. (2001). Enrichment of neurons and neural precursors from human embryonic stem cells. Experimental Neurology, Vol.172, No. 2, (December 2001), pp. 383-397, ISSN 00144886.

Castillo, C.G., Mendoza-Trejo, S., Aguilar, M.B., Freed, W.J. \& Giordano, M. (2008). Intranigral transplants of a GABAergic cell line produce long-term alleviation of established motor seizures. Behavioural Brain Research, Vol.193, No. 1, (November 2008), pp. 17-27, ISSN 0166-4328.

Castillo, C.G., Mendoza, S., Freed, W.J. \& Giordano, M. (2006). Intranigral transplants of immortalized GABAergic cells decrease the expression of kainic acid-induced seizures in the rat. Behavioural Brain Research, Vol.171, No. 1, (July 2006), pp. 109115, ISSN 0166-4328.

Castillo, C.G., Mendoza, S., Saavedra, J. \& Giordano, M. (2010) Lack of effect of intranigral transplants of a GABAergic cell line on absence seizures. Epilepsy and Behavior, Vol.18, No. 4, (August 2010), pp. 358-365, ISSN 1525-5069.

Chu,K., Kim M., Jung, K.-H., Jeon D., Lee, S.-T., Kim, J., Jeong , S.-W., Kim, S.U., Lee, S.K., Shin, H-.S., \& Roh, J.-K. (2004). Human neural stem cell transplantation reduces spontaneous recurrent seizures following pilocarpine-induced status epilepticus in adult rats. Brain research, Vol.1023, No. 2, (September 2004), pp. 213-221, ISSN 0006-8993.

Conejero-Goldberg, C., Tornatore, C., Abi-Saab, W., Monaco, M.C., Dillon-Carter, O., Vawter, M., Elsworth, J. \& Freed, W. (2000). Transduction of human GAD67 cDNA 
into immortalized striatal cell lines using an Epstein-Barr virus-based plasmid vector increases GABA content. Experimental Neurology, Vol.161, No. 2, (February 2000), pp. 453-461, ISSN 0014-4886.

Cooper, O., Astradsson, A.,Hallett, P., Robertson, H., Mendez, I.,Isacson, O. (2009). Lack of functional relevance of isolated cell damage in transplants of Parkinson's disease patients, Journal of Neurology, Vol.256 Suppl. 3, (September 2009), pp. 310-316, ISSN 1432-1459.

Cossart, R., Dinocourt, C., Hirsch, J.C., Merchan-Perez, A., De Felipe, J., Ben-Ari, Y., Esclapez, M. \& Bernard, C. (2001). Dendritic but not somatic GABAergic inhibition is decreased in experimental epilepsy. Nature Neuroscience, Vol.4, No. 1, (January 2001), pp. 52-62, ISSN 1097-6256.

Costa-Ferro Z.S.M., Vitola A.S., Pedroso M.F., Cunha F.B., Xavier L.L., Machado D.C., Soares M.B.P., Ribeiro-dos-Santos R., \& DaCosta J.C. (2010). Prevention of seizures and reorganization of hippocampal functions by transplantation of bone marrow cells in the acute phase of experimental epilepsy. Seizure, Vol.19, No.2, (March 2010), pp. 84-92, ISSN 1532-2688.

Drucker-Colin, R. \& Verdugo-Diaz, L. (2004). Cell transplantation for Parkinson's disease: present status. Cellular and Molecular Neurobiology, Vol.24, No. 3, (June 2004), pp. 301-316, ISSN 0272-4340.

Dunnett, S.B., Low, W.C., Iversen, S.D., Stenevi, U. \& Bjorklund, A. (1982). Septal transplants restore maze learning in rats with fornix-fimbria lesions. Brain Research, Vol. 251, No. 2, (November 1982), pp. 335-348, 0006-8993.

Fine, A., Meldrum, B.S. \& Patel, S. (1990). Modulation of experimentally induced epilepsy by intracerebral grafts of fetal GABAergic neurons. Neuropsychologia, Vol.28, No. 6, (January 1990) pp. 627-634, ISSN 0028-3932.

Fink, J.S., Schumacher, J.M., Ellias, S.L., Palmer, E.P., Saint-Hilaire, M., Shannon, K., Penn, R., Starr, P., VanHorne, C., Kott, H.S., Dempsey, P.K., Fischman, A.J., Raineri, R., Manhart, C., Dinsmore, J. \& Isacson, O. (2000). Porcine xenografts in Parkinson's disease and Huntington's disease patients: preliminary results. Cell Transplantation, Vol 9, No. 2, (March-April 2000), pp. 273-278, ISSN 0963-6897.

Freed, C.R., Greene, P.E., Breeze, R.E., Tsai, W.Y., DuMouchel, W., Kao, R., Dillon, S., Winfield, H., Culver, S., Trojanowski, J.Q., Eidelberg, D. \& Fahn, S. (2001). Transplantation of embryonic dopamine neurons for severe Parkinson's disease. New England Journal of Medicine, Vol.344, No. 10, (March 2001), pp. 710-719, ISSN 0028-4793.

Freed, W.J. (1993) Neural transplantation: Prospects for clinical use. Cell Transplantation, Vol.2, (January 1993), pp 13-31, ISSN 0963-6897.

Freed, W.J., Poltorak, M. \& Becker, J.B. (1990). Intracerebral adrenal medulla grafts: a review. Experimental Neurology, Vol.110, No. 2, (November 1990), pp. 139-166, ISSN 00144886.

Freed, W.J., Poltorak, M., Takashima, H., LaMarca, M.E. \& Ginns, E.I. (1991). Brain grafts and Parkinson's disease. Journal of Cellular Biochemistry, Vol.45, No. 3, (March 1991), pp. 261-267, ISSN0730-2312.

Gale, K. (1992). GABA and epilepsy: basic concepts from preclinical research. Epilepsia, Vol.33 Suppl. 5, (January 1992), pp. S3-S12, ISSN 0013-9580. 
Gash, D., Sladek, J.R., Jr. \& Sladek, C.D. (1980). Functional development of grafted vasopressin neurons. Science, Vol.210, No. 4476, (December 1980), pp. 1367-1369, ISSN 0036-8075.

Gernert, M., Thompson, K.W., Loscher, W. \& Tobin, A.J. (2002). Genetically engineered GABA-producing cells demonstrate anticonvulsant effects and long-term transgene expression when transplanted into the central piriform cortex of rats. Experimental Neurology, Vol.176, No. 1, (July 2002), pp. 183-92, ISSN 0014-4886.

Giordano, M., Takashima, H., Herranz, A., Poltorak, M., Geller, H.M., Marone, M. \& Freed, W.J. (1993). Immortalized GABAergic cell lines derived from rat striatum using a temperature-sensitive allele of the SV40 large T antigen. Experimental Neurology, Vol 124, No. 2, (December 1993), pp. 395-400, ISSN 0014-4886.

Giordano, M., Takashima, H., Poltorak, M., Geller, H.M. \& Freed, W.J. (1996). Constitutive expression of glutamic acid decarboxylase (GAD) by striatal cell lines immortalized using the tsA58 allele of the SV40 large T antigen. Cell Transplantation, Vol.5, No. 5, (September-October 1996), pp. 563-575, ISSN 0963-6897.

Goetz, C.G., Poewe, W., Rascol, O. \& Sampaio, C. (2005). Evidence-based medical review update: pharmacological and surgical treatments of Parkinson's disease: 2001 to 2004. Movement Disorders, Vol.20, No. 5, (May 2005), pp. 523-539, ISSN 0885-3185.

Guttinger, M., Fedele, D., Koch, P., Padrun, V., Pralong, W.F., Brustle, O. \& Boison, D. (2005). Suppression of kindled seizures by paracrine adenosine release from stem cell-derived brain implants. Epilepsia, Vol.46, No. 8, (August 2005), pp. 1162-1169, ISSN 0013-9580.

Hattiangady, B., Rao, M.S. \& Shetty, A.K. (2008). Grafting of striatal precursor cells into hippocampus shortly after status epilepticus restrains chronic temporal lobe epilepsy. Experimental Neurology, Vol.212, No. 2, (August 2008), pp. 468-481, ISSN 1090-2430.

Isacson, O., \&. Kordower, J.H. (2008) Future of Cell and Gene Therapies for Parkinson's Disease. Annals of Neurology, Vol.64, Suppl. 2, (December 2008), pp. S122-S138, ISSN 1531-8249.

Jing, M., Shingo, T., Yasuhara, T., Kondo, A., Morimoto, T., Wang, F., Baba, T., Yuan W.J., Tajiri,N., Uozumi, T., Murakami, M., Tanabe, M., Miyoshi, Y., Zhao, S., \& Date, I. (2009). The combined therapy of intrahippocampal transplantation of adult neural stem cells and intraventricular erythropoietin-infusion ameliorates spontaneous recurrent seizures by suppression of abnormal mossy fiber sprouting. Brain Research, Vol.1295, (October 2009), pp. 203-211, ISSN 1872-6240.

Kanter-Schlifke, I., Fjord-Larsen, L., Kusk, P., Angehagen, M., Wahlberg, L. \& Kokaia, M. (2009). GDNF released from encapsulated cells suppresses seizure activity in the epileptic hippocampus. Experimental Neurology, Vol.216, No. 2, (April 2009), pp. 413-419, ISSN 1090-2430.

Kim, J.H., Auerbach, J.M., Rodriguez-Gomez, J.A., Velasco, I., Gavin, D., Lumelsky, N., Lee, S.H., Nguyen, J., Sanchez-Pernaute, R., Bankiewicz, K. \& McKay, R. (2002). Dopamine neurons derived from embryonic stem cells function in an animal model of Parkinson's disease. Nature, Vol.418, No. 6893, (July 2002), pp. 50-56, ISSN 00280836. 
Kim, S.U. (2004). Human neural stem cells genetically modified for brain repair in neurological disorders. Neuropathology, Vol.24, No. 2, (September 2004), pp. 159171, ISSN 0919-6544.

Kokaia, M., Aebischer, P., Elmer, E., Bengzon, J., Kalen, P., Kokaia, Z. \& Lindvall, O. (1994). Seizure suppression in kindling epilepsy by intracerebral implants of GABA- but not by noradrenaline-releasing polymer matrices. Experimental Brain Research, Vol.100, No. 3, (January 1994), pp. 385-394, ISSN 0014-4819.

Kordower, J.H., Chu, Y., Hauser, R.A., Freeman, T.B. \& Olanow, C.W. (2008). Lewy bodylike pathology in long-term embryonic nigral transplants in Parkinson's disease. Nature Medicine, Vol.14, No. 5, (May 2008), pp. 504-506, ISSN 1546-170X.

Kovari, E., Horvath, J. \& Bouras, C. (2009). Neuropathology of Lewy body disorders. Brain Res Bull, Vol.80, No. 4-5, (October 2009), pp. 203-210, ISSN 1873-2747.

Labandeira-Garcia, J.L. \& Guerra, M.J. (1994). Cortical stimulation induces fos expression in intrastriatal striatal grafts. Brain Research, Vol.652, No. 1, (July 1994), pp. 87-97, ISSN 0006-8993.

Lang, K.J., Rathjen, J., Vassilieva, S. \& Rathjen, P.D. (2004). Differentiation of embryonic stem cells to a neural fate: a route to re-building the nervous system? Journal of Neuroscience Research, Vol.76, No. 2, (April 2004), pp. 184-192, ISSN 0360-4012.

Lee, G., Chambers, S.M., Tomishima, M.J. \& Studer, L. Derivation of neural crest cells from human pluripotent stem cells. (2010). Nature Protocols, Vol.5, No. 4, (April 2010), pp. 688-701, ISSN 1750-2799.

Li, J. Y., Englund, E., Holton, J. L., Soulet, D., Hagell, P., Lees, A. J., Lashley, T., Quinn, N. P., Rehncrona, S., Bjorklund, A., Widner, H., Revesz, T., Lindvall, O., \& Brundin, P. (2008). Lewy bodies in grafted neurons in subjects with Parkinson's disease suggest host-to-graft disease propagation. Nature Medicine, Vol.14, No. 5, (May 2008), pp. 501-503, ISSN 1546-170X.

Li, T., Steinbeck, J. A., Lusardi, T., Koch, P., Lan, J. Q., Wilz, A., Segschneider, M., Simon, R. P., Brustle, O., \& Boison, D. (2007). Suppression of kindling epileptogenesis by adenosine releasing stem cell-derived brain implants. Brain,Vol. 130, Pt.5, (May 2007), pp. 1276-1288, ISSN 1460-2156.

Lindvall, O., \& Bjorklund, A. (2004) Cell therapy in Parkinson's disease. NeuroRx, Vol.1, No. 4, (October 2004), pp. 382-393, ISSN 1545-5343.

Loscher, W., Ebert, U., Lehmann, H., Rosenthal, C. \& Nikkhah, G. (1998). Seizure suppression in kindling epilepsy by grafts of fetal GABAergic neurons in rat substantia nigra. Journal of Neuroscience Research, Vol. 51, No. 2, (January 1998), pp. 196-209, ISSN 0360-4012.

Ma, Y., Tang, C., Chaly, T., Greene, P., Breeze, R., Fahn, S., Freed, C., Dhawan, V. \& Eidelberg, D. (2010). Dopamine cell implantation in Parkinson's disease: long-term clinical and (18)F-FDOPA PET outcomes. Journal of Nuclear Medicine, Vol.51, No. 1, (January 2010), pp. 7-15, ISSN 1535-5667.

Maisano, X., Carpentino, J., Becker, S., Lanza, R., Aaron, G., Grabel, L. \& Naegele, J.R. (2009). Embryonic stem cell-derived neural precursor grafts for treatment of temporal lobe epilepsy. Neurotherapeutics, Vol 6, No. 2, (April 2009), pp. 263-277, ISSN 1933-7213.

Mejía-Toiber, J., Castillo, C.G., \& Giordano, M. (in press). Strategies for the development of cell lines for ex vivo gene therapy in the central nervous system. Cell transplantation. 
Mejia-Toiber, J., Marquez-Ramos, J.A., Diaz-Munoz, M., Pena, F., Aguilar, M.B. \& Giordano, M. Glutamatergic excitation and GABA release from a transplantable cell line. Cell Transplant, Vol 19, No. 10, (June 2010), pp. 1307-1323, ISSN 1555-3892.

Mendez, I., Vinuela, A., Astradsson, A., Mukhida, K., Hallett, P., Robertson, H., Tierney, T., Holness, R., Dagher, A., Trojanowski, J.Q. \& Isacson, O. (2008). Dopamine neurons implanted into people with Parkinson's disease survive without pathology for 14 years. Nature Medicine, Vol.14, No. 5, (May 2008), pp. 507-509, ISSN 1546-170X.

Morimoto, K., Fahnestock, M. \& Racine, R.J. (2004). Kindling and status epilepticus models of epilepsy: rewiring the brain. Progress in Neurobiology, Vol.73, No. 1, (May 2004), pp. 1-60, ISSN 0301-0082.

Muller, F. J., Snyder, E. Y., \& Loring, J. F. (2006) Gene therapy: can neural stem cells deliver? Nature reviews. Neuroscience, Vol.7, No. 1, (January 2006), pp. 75-84, ISSN 1471-003X.

Murata, Y., Chiba, T., Brundin, P., Bjorklund, A. \& Lindvall, O. (1990). Formation of synaptic graft-host connections by noradrenergic locus coeruleus neurons transplanted into the adult rat hippocampus. Experimental Neurology, Vol.110, No. 3, (December 1990), pp. 258-267, ISSN 0014-4886.

Nolte, M.W., Löscher, W., Herden, C., Freed, W.J. \& Gernert, M. (2008). Benefits and risks of intranigral transplantation of GABA-producing cells subsequent to the establishment of kindling-induced seizures. Neurobiology of Disease, Vol .1, No. 3, (September 2008), pp. 342-354, ISSN 1095-953X.

Norman, A.B., Lehman, M.N. \& Sanberg, P.R. (1989). Functional effects of fetal striatal transplants. Brain Research Bulletin, Vol.22, No. 1, (January 1989), pp. 163-172, ISSN 0361-9230.

Nottebohm, F. (2002). Neuronal replacement in adult brain. Brain Research Bulletin, Vol.57, No. 6, (April 2002), pp. 737-749, ISSN 0361-9230.

Olanow, C.W., Goetz, C.G., Kordower, J.H., Stoessl, A.J., Sossi, V., Brin, M.F., Shannon, K.M., Nauert, G.M., Perl, D.P., Godbold, J. \& Freeman, T.B. (2003). A double-blind controlled trial of bilateral fetal nigral transplantation in Parkinson's disease. Annals of Neurology, Vol.54, No. 3, (September 2003), pp. 403-414, ISSN 0364-5134.

Pan, Y., Chen, X., Wang, S., Yang, S., Bai, X., Chi, X., Li, K., Liu, B. \& Li, L. (2005). In vitro neuronal differentiation of cultured human embryonic germ cells. Biochemical and Biophysical Research Communications, Vol.327, No. 2, (February 2005), pp. 548-556, ISSN 0006-291X.

Perrier, A.L., Tabar, V., Barberi, T., Rubio, M.E., Bruses, J., Topf, N., Harrison, N.L. \& Studer, L. (2004). Derivation of midbrain dopamine neurons from human embryonic stem cells. Proceedings of the National Academy of Science U S A, Vol.101, No. 34, (August 2004), pp. 12543-12548, ISSN 0027-8424.

Piccini, P., Pavese, N., Hagell, P., Reimer, J., Bjorklund, A., Oertel, W.H., Quinn, N.P., Brooks, D.J. \& Lindvall, O. (2005). Factors affecting the clinical outcome after neural transplantation in Parkinson's disease. Brain, Vol.128, Pt 12, (December 2005), pp. 2977-2986, ISSN 1460-2156.

Rao, M. S., Hattiangady, B., Rai, K. S., \& Shetty, A. K. (2007). Strategies for promoting antiseizure effects of hippocampal fetal cells grafted into the hippocampus of rats exhibiting chronic temporal lobe epilepsy. Neurobiology of disease, Vol.27, No. 2 (August 2007), pp. 117-132, ISSN 0969-9961. 
Reubinoff, B.E., Itsykson, P., Turetsky, T., Pera, M.F., Reinhartz, E., Itzik, A. \& Ben-Hur, T. (2001). Neural progenitors from human embryonic stem cells. Nature Biotechnology, Vol.19, No. 12, (December 2001), pp. 1134-1140, ISSN 1087-0156.

Rodriguez-Gomez, J.A., Lu, J.Q., Velasco, I., Rivera, S., Zoghbi, S.S., Liow, J.S., Musachio, J.L., Chin, F.T., Toyama, H., Seidel, J., Green, M.V., Thanos, P.K., Ichise, M., Pike, V.W., Innis, R.B. \& McKay, R.D. (2007). Persistent dopamine functions of neurons derived from embryonic stem cells in a rodent model of Parkinson disease. Stem Cells, Vol.25, No. 4, (April 2007), pp. 918-928, ISSN 1066-5099.

Roitberg, B., Shin, P., Sramek, J., \& Kordower, J.H. (2000). Neural grafting for Parkinson's and Huntington's disease, In: Central nervous system diseases: innovative animal models from lab to clinic, D.F. Emerich, R.L. Dean III, P.R. Sanberg (Eds.), pp. 441-483, Humana Press Ic, 0-89603-724-X, Totowa, NJ.

Ross, K.C., Waldman, B.C., Conejero-Goldberg, C., Freed, W. \& Coleman, J.R. (2002). Transplantation of M213-2O cells with enhanced GAD67 expression into the inferior colliculus alters audiogenic seizures. Experimental Neurology, Vol.177, No. 1, (September 2002), pp. 338-340, ISSN 0014-4886.

Ruschenschmidt, C., Koch, P.G., Brustle, O. \& Beck, H. (2005). Functional properties of ES cell-derived neurons engrafted into the hippocampus of adult normal and chronically epileptic rats. Epilepsia, Vol.46 Suppl. 5, pp. 174-183, ISSN 0013-9580.

Rutherford, A., Garcia-Munoz, M., Dunnett, S.B. \& Arbuthnott, G.W. (1987). Electrophysiological demonstration of host cortical inputs to striatal grafts. Neuroscience Letters, Vol.83, No. 3, (December 1987), pp. 275-281, ISSN 0304-3940.

Shetty, A.K. \& Hattiangady, B. (2007). Concise review: prospects of stem cell therapy for temporal lobe epilepsy. Stem Cells, Vol.25, No. 10, (October 2007), pp. 2396-2407, ISSN 1549-4918.

Snyder, E. Y., Daley, G. Q., \& Goodell, M. (2004). Taking stock and planning for the next decade: realistic prospects for stem cell therapies for the nervous system Journal of neuroscience research. Journal of neuroscience research, Vol.76, No. 2, (April 2004), pp. 157-168, ISSN 0360-4012.

Storch, A., Sabolek, M., Milosevic, J., Schwarz, S. C., \& Schwarz, J. (2004). Midbrain-derived neural stem cells: from basic science to therapeutic approaches. Cell and tissue research, Vol.318, No. 1 (October 2004), pp. 15-22, ISSN 0302-766X.

Takahashi, K. \& Yamanaka, S. (2006). Induction of pluripotent stem cells from mouse embryonic and adult fibroblast cultures by defined factors. Cell, Vol.126, No. 4, (August 2006), pp. 663-676, ISSN 0092-8674.

Thompson, K.W. (2005). Genetically engineered cells with regulatable GABA production can affect afterdischarges and behavioral seizures after transplantation into the dentate gyrus. Neuroscience, Vol.133, No. 4, (June 2005), pp. 1029-1037, ISSN 0306-4522.

Thompson, K., Anantharam, V., Behrstock, S., Bongarzone, E., Campagnoni, A. \& Tobin, A.J. (2000). Conditionally immortalized cell lines, engineered to produce and release GABA, modulate the development of behavioral seizures. Experimental Neurology, Vol.161, No. 2, (February 2000), pp. 481-489, ISSN 0014-4886.

Thompson, K.W. \& Suchomelova, L.M. (2004). Transplants of cells engineered to produce GABA suppress spontaneous seizures. Epilepsia, Vol.45, No. 1, (January 2004), pp. 4-12, ISSN 0013-9580. 
Tolosa, E., Wenning, G. \& Poewe, W. (2006). The diagnosis of Parkinson's disease. Lancet Neurology, Vol.5, No. 1, (January 2006), pp. 75-86, ISSN 1474-4422.

Ungerstedt, U. (1968). 6-Hydroxy-dopamine induced degeneration of central monoamine neurons. European Journal of Pharmacology, Vol.5, No. 1, (December 1968), pp. 107110, ISSN 0014-2999.

Ungerstedt, U. \& Arbuthnott, G.W. (1970). Quantitative recording of rotational behavior in rats after 6-hydroxy-dopamine lesions of the nigrostriatal dopamine system. Brain Research, Vol.24, No. 3, (December 1970), pp. 485-493, ISSN 0006-8993.

Vazin, T. \& Freed, W.J. Human embryonic stem cells: derivation, culture, and differentiation: a review. Restorative Neurology and Neuroscience, Vol.28, No. 4, (January 2010), pp. 589-603, ISSN 0922-6028.

Waldau, B., Hattiangady, B., Kuruba, R., \& Shetty, A. K. (2010) Medial ganglionic eminencederived neural stem cell grafts ease spontaneous seizures and restore GDNF expression in a rat model of chronic temporal lobe epilepsy. Stem cells, Vol. 28, No. 7, (July 2010), pp. 1153-1164, ISSN 1549-4918.

Wang, Y., Chen, S., Yang, D., \& Le, W. D. (2007). Stem cell transplantation: a promising therapy for Parkinson's disease. Journal of neuroimmune pharmacology, Vol.2, No. 3, (September 2007), pp. 243-250,ISSN 1557-1904.

Westmoreland, J.J., Hancock, C.R. \& Condie, B.G. (2001). Neuronal development of embryonic stem cells: a model of GABAergic neuron differentiation. Biochemical and Biophysical Research Communications, Vol.284, No. 3, (June 2001), pp. 674-680, ISSN 0006-291X.

Wictorin, K. (1992). Anatomy and connectivity of intrastriatal striatal transplants. Progress in Neurobiology, Vol.38, No. 6, (June 1992), pp. 611-639, ISSN 0301-0082.

Winkler, C., Kirik, D., \& Bjorklund, A. (2005). Cell transplantation in Parkinson's disease: how can we make it work? Trends in neurosciences, Vol.28, No.2, (February 2005), pp. 86-92, ISSN 0166-2236.

Xu, Z.C., Wilson, C.J. \& Emson, P.C. (1991). Synaptic potentials evoked in spiny neurons in rat neostriatal grafts by cortical and thalamic stimulation. J Neurophysiol, Vol 65, No. 3, (Mar), pp. 477-493, ISSN 0022-3077.

Yu, J., \& Thomson, J. A. (2008). Pluripotent stem cell lines. Genes $\mathcal{E}$ development, Vol.22, No.15, (August 2008), pp. 1987-1997, ISSN 0890-9369.

Zhang, S.C., Wernig, M., Duncan, I.D., Brustle, O. \& Thomson, J.A. (2001). In vitro differentiation of transplantable neural precursors from human embryonic stem cells. Nature Biotechnoogyl, Vol.19, No. 12, (December 2001), pp. 1129-1133, ISSN 1087-0156. 


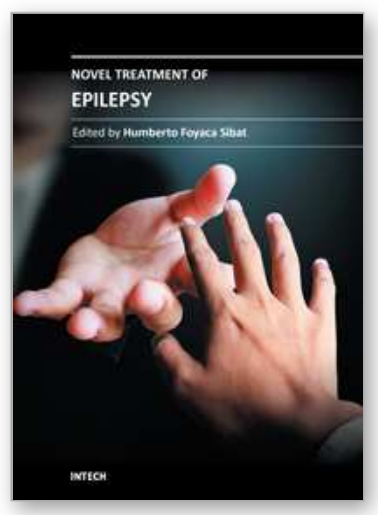

\author{
Novel Treatment of Epilepsy \\ Edited by Prof. Humberto Foyaca-Sibat
}

ISBN 978-953-307-667-6

Hard cover, 326 pages

Publisher InTech

Published online 22, September, 2011

Published in print edition September, 2011

Epilepsy continues to be a major health problem throughout the planet, affecting millions of people, mainly in developing countries where parasitic zoonoses are more common and cysticercosis, as a leading cause, is endemic. There is epidemiological evidence for an increasing prevalence of epilepsy throughout the world, and evidence of increasing morbidity and mortality in many countries as a consequence of higher incidence of infectious diseases, head injury and stroke. We decided to edit this book because we identified another way to approach this problem, covering aspects of the treatment of epilepsy based on the most recent technological results â€œin vitroâ€ from developed countries, and the basic treatment of epilepsy at the primary care level in rural areas of South Africa. Therefore, apart from the classic issues that cannot be missing in any book about epilepsy, we introduced novel aspects related with epilepsy and neurocysticercosis, as a leading cause of epilepsy in developing countries. Many experts from the field of epilepsy worked hard on this publication to provide valuable updated information about the treatment of epilepsy and other related problems.

\title{
How to reference
}

In order to correctly reference this scholarly work, feel free to copy and paste the following:

Magda Giordano (2011). The Role of Cell Therapy in the Treatment of Epilepsy: Lessons from Animal Models and Clinical Trials, Novel Treatment of Epilepsy, Prof. Humberto Foyaca-Sibat (Ed.), ISBN: 978-953-307-6676, InTech, Available from: http://www.intechopen.com/books/novel-treatment-of-epilepsy/the-role-of-celltherapy-in-the-treatment-of-epilepsy-lessons-from-animal-models-and-clinical-trials

\section{INTECH}

open science | open minds

\section{InTech Europe}

University Campus STeP Ri

Slavka Krautzeka 83/A

51000 Rijeka, Croatia

Phone: +385 (51) 770447

Fax: +385 (51) 686166

www.intechopen.com

\section{InTech China}

Unit 405, Office Block, Hotel Equatorial Shanghai

No.65, Yan An Road (West), Shanghai, 200040, China

中国上海市延安西路65号上海国际贵都大饭店办公楼 405 单元

Phone: +86-21-62489820

Fax: $+86-21-62489821$ 
(C) 2011 The Author(s). Licensee IntechOpen. This chapter is distributed under the terms of the Creative Commons Attribution-NonCommercialShareAlike-3.0 License, which permits use, distribution and reproduction for non-commercial purposes, provided the original is properly cited and derivative works building on this content are distributed under the same license. 